\title{
NOTE
}

\section{Mercury in sediments from the Okhotsk Sea and Funka Bay}

\author{
Katsuhiko Matsunaga ${ }^{1}$, Sigeru Montani ${ }^{1}$, Ryusuke Kobayashi ${ }^{1}$, \\ Yoshiaki Maita $^{1}$, Sigeru FuKase ${ }^{1}$ and Jiro ISHII ${ }^{2}$ \\ Department of Chemistry, Faculty of Fisheries, Hokkaido University, \\ Hakodate, $041^{1}$ and Tokai University, Sapporo, 061-2 $1^{2}$ Japan
}

(Received March 20, 1978; accepted in revised form August 18, 1978)

\begin{abstract}
Mercury and organic nitrogen were determined in sediment cores taken from the Okhotsk Sea and Funka Bay in northern Japan. The concentrations of mercury and organic nitrogen in the cores decrease from the surface to a nearly constant value below $20-50 \mathrm{~cm}$ depth. Mercury is strongly correlated with organic nitrogen in each core, showing association of mercury with organic matter. Copper, zinc, iron and lead were also determined in some cores but showed no systematic variation with depth. Methylmercury both in interstitial waters and in solid phases was determined for some Funka Bay cores. The profiles appear to suggest that the mercury is lost from the sediments during early diagenesis by forming methylmercury or its sulfur derivatives.
\end{abstract}

\section{INTRODUCTION}

Vertical distributions of mercury concentration in lake and marine core sediments have been reported by AsToN et al. (1973) and Young et al. (1973). The profiles showed that the mercury concentrations were high in the surface and decreased with depth. Based on the observations, they suggested that the high mercury concentration in the surface sediments is due to increasing supply by man's activities on a global scale. Recently CowgILL (1975) reported similar results in recently deposited Hueh Lake muds.

On the other hand, Sikes and Drain (1973) have demonstrated that, except for sediments from areas known to have been contaminated with mercury, the higher mercury concentration in the surface sediments is due not to increased anthropogenic loading but to natural processes. They suggested that corpora of aquatic organisms, which can concentrate mercury in their bodies, are deposited on the surface of sea bottom, thus adding significant amounts of mercury to the upper sediments. Further they suggested that the life cycle of benthic organisms offers a particularly striking pathway whereby mercury could be carried upward and ultimately deposited at the sediment-water interface. Obviously, more investigations are needed to solve the mechanism of mercury enrichment in the surface of sediments.
Here we report the results on mercury, organic nitrogen and trace metals in marine sediments taken from the Okhotsk Sea and Funka Bay. Based on the results, an alternative explanation for high mercury concentrations in the surface sediments is presented.

\section{EXPERIMENTAL}

Core samples: Twelve core samples were collected by a gravity corer from the Okhotsk Sea during the 13 cruise of the $R / V$ Mendeleev from August to September, 1974. The sampling sites are shown in Fig. 1. In addition, three cores were collected in August, 1975 at two stations in Funka Bay (Fig. 1), which are presumably uncontaminated by human activities. The core samples from the Okhotsk Sea and one of the cores from each station in the Bay were kept at $-20^{\circ} \mathrm{C}$ prior to analysis. In the laboratory the cores were sliced into $5 \mathrm{~cm}$ intervals and vacuum dried. Other core samples from Funka Bay were also cut into blocks of $5 \mathrm{~cm}$ in length, and interstitial waters were separated by centrifugation. Methylmercury was determined in both sediments and interstitial waters.

The outline of the analytical method for total mercury is as follows (Nishimura et al., 1975): $0.1-0.5 \mathrm{~g}$ of sediment passed through a $100 \mu \mathrm{m}$ sieve was heated for $2 \mathrm{hr}$ in a reflux condenser after adding $2 \mathrm{ml}$ of concentrated 


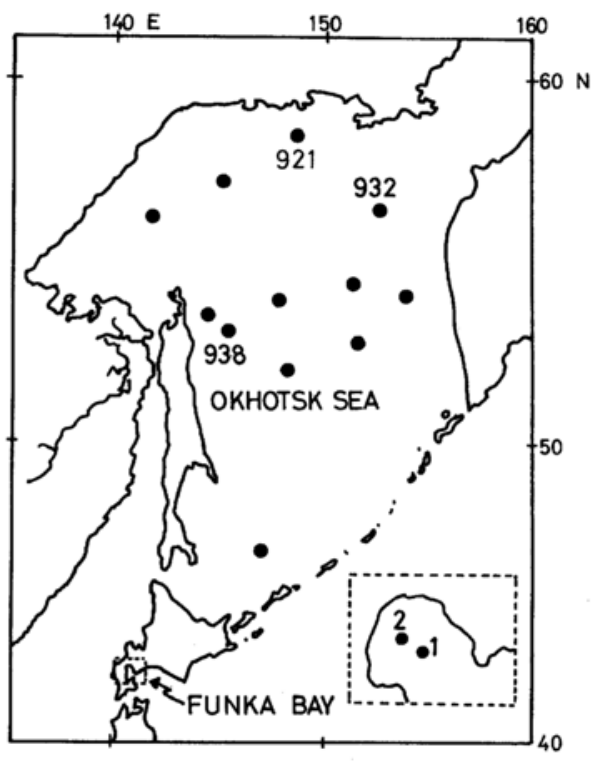

Fig. 1. Sampling stations in the Okhotsk Sea and Funka Bay.

sulfuric acid and $5 \mathrm{ml}$ of concentrated nitric acid. Mercury was then reduced with stannous chloride and any ensuing mercury vapour was transferred by nitrogen gas to gold particles packed in a glass tube. The resulting amalgam is heated in a furnace at $500^{\circ} \mathrm{C}$, and the vapourized mercury is determined by atomic absorption spectrophotometry. Methylmercury was extracted into benzene, back-extracted into glutathione-ammonia solution and measured by atomic absorption spectrophotometry (MATSUNAGA and TAKAHASHI, 1976). Identification of methylmercury in some samples was carried out by gas chromatography with an electron capture detector. It was found that organic mercury extracted into benzene was all methylmercury. Organic nitrogen and carbon were determined by a carbon nitrogen analyser. After a total digestion in hydrofluoric/perchloric/nitric acid, copper, zinc, iron and lead were measured by atomic absorption spectrophotometry. The relative standard deviations of 5 replicate determinations of elements in a marine sediment sample were $20,15,1$ and $1 \%$ at 2 ng methylmercury, $100 \mathrm{ng}$ inorganic mercury, $10 \mathrm{mg}$ carbon and $2 \mathrm{mg}$ absolute level of nitrogen, respectively. The relative standard deviations of 5 replicate determinations of other heavy metals in a marine sediment sample were less than $15 \%$.

\section{RESUlts AND Discussion}

The vertical profiles of mercury, organic nitrogen and carbon in the core from Stn. 938 are shown in Fig. 2. Mercury and organic nitrogen in other cores except for the one from Stn. 932 which is diatomaceous ooze show similar depth profiles. The relationship between mercury and nitrogen in some selected cores are shown in Fig. 3. In these cores, mercury correlates with organic nitrogen at $95 \%$ confidence limit and in some other core samples there is also a strong correlation between mercury and organic carbon. The core from Stn. 932, however, shows that mercury, nitrogen and carbon concentrations are nearly constant with depth within the limits of analytical errors.

The vertical distirbutions of methylmercury concentrations both in sediments and in interstitial waters for the cores from Funka Bay are shown in Fig. 4. Methylmercury in interstitial waters increases with depth, whereas that in sediments decreases with depth. The sharp increase of methylmercury in interstitial waters suggests that the significant amount of mercury diffuses out of the sediment.

Methylation of inorganic mercury in sediments (JENSEN and JERNELOV, 1969; JERNELOV, 1970; LANGLEY, 1973; SPANGLER et al. 1973) and its existence in natural sediments (ANDREN and HARRISS 1973; BATTI et al., 1975) have been reported. Recently RowLAND et al. (1977)

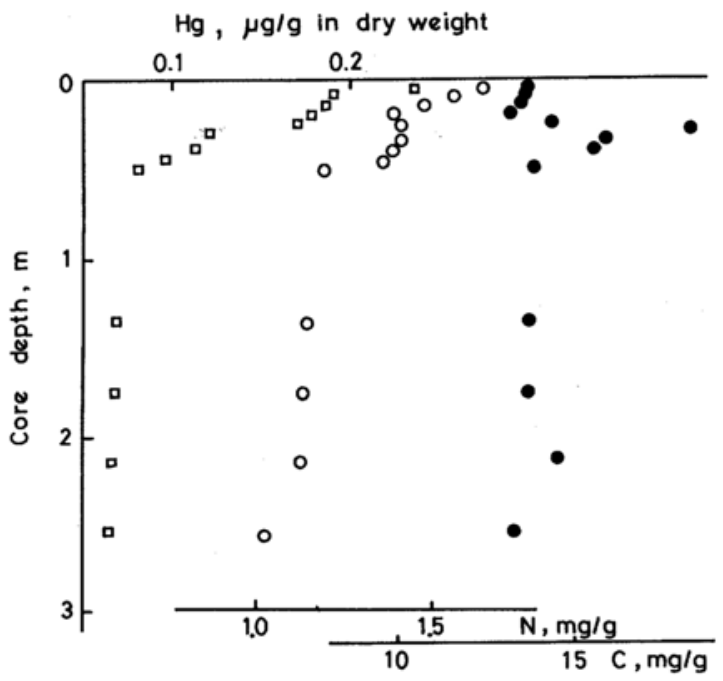

Fig. 2. Total mercury, organic nitrogen and carbon concentrations in sediments at Stn. 938. ․: Hg; ०: organic $N$; •: organic $C$. 


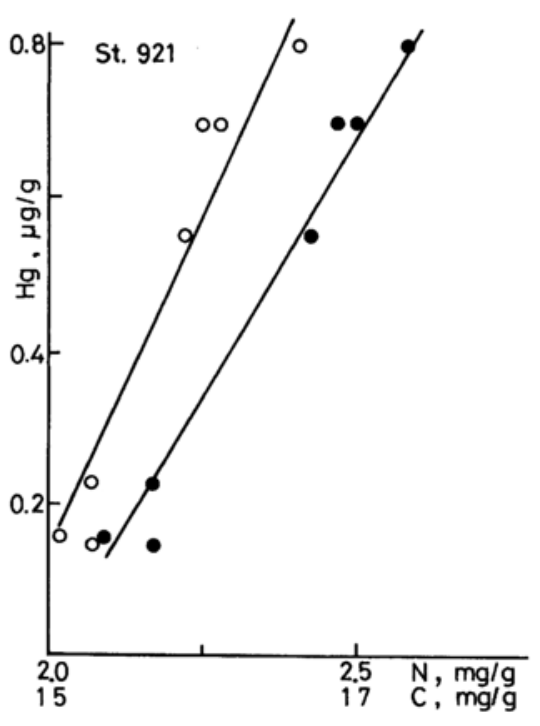

Fig. 3a

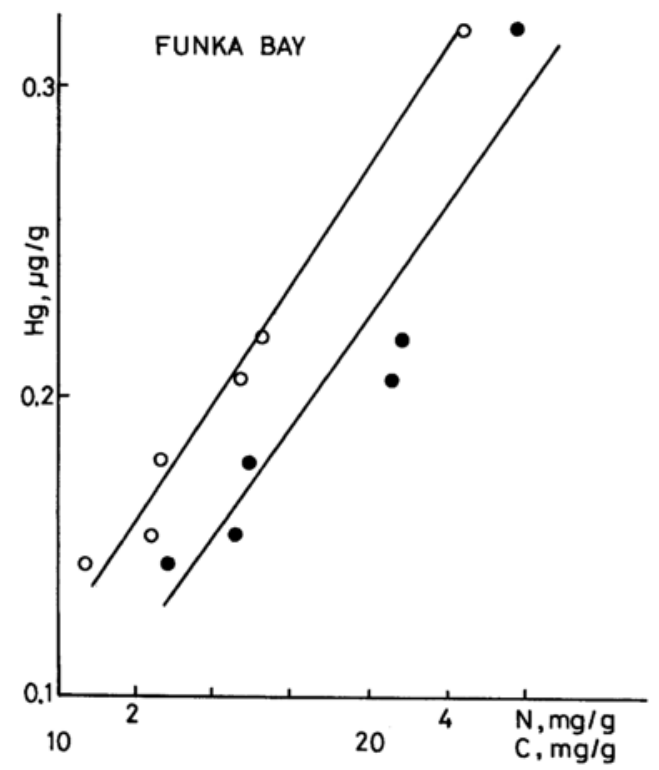

Fig. 3b

Fig. 3. Relation between total mercury and organic nitrogen or carbon. $\mathrm{Hg}$ is plotted for organic $\mathrm{N}(\mathrm{O})$ and for organic $C(\bullet)$.

$a$ : Stn. 921, 58-34.0N, 148-14.0E, water depth is $128 \mathrm{~m}$.

$r=0.965$ for $N, r=0.987$ for $C$

$b$ : Funka Bay (Stn. 1), 42-16.2N, 140-36.0E, water depth is $90 \mathrm{~m}$.

$r=0.971$ for $N, r=0.942$ for $C$

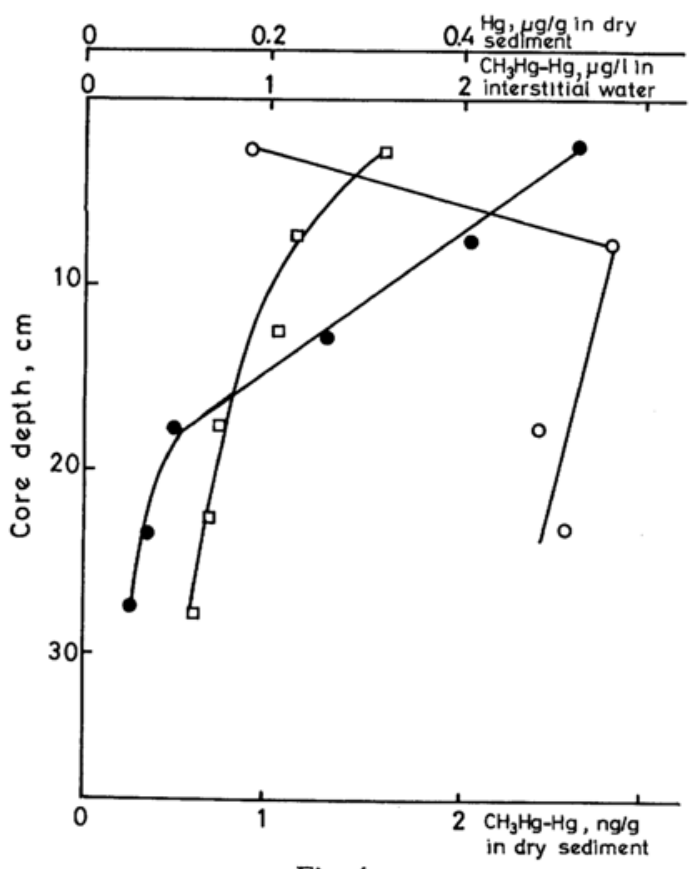

Fig. 4a

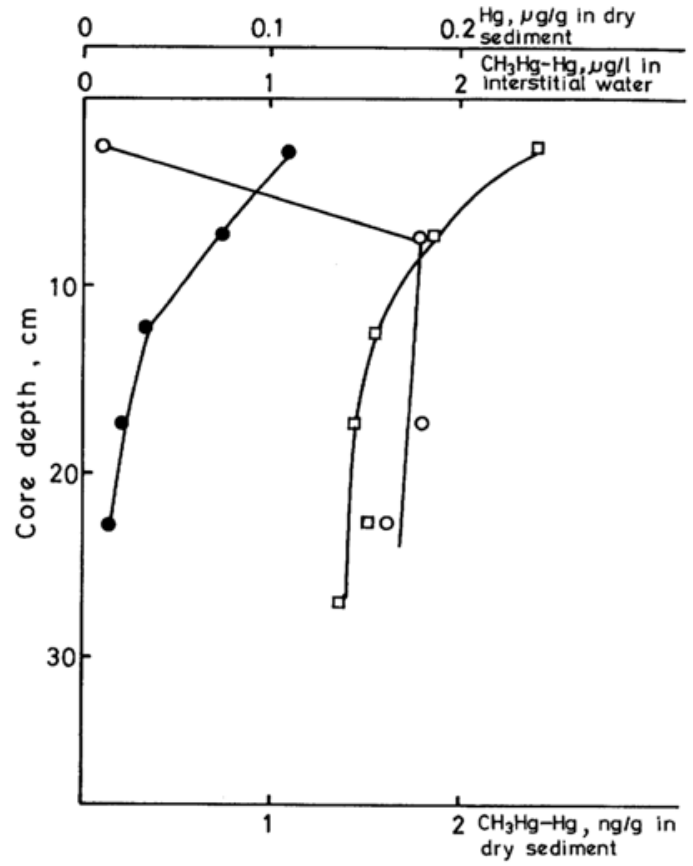

Fig. 4b

Fig. 4. Total and methylmercuric mercury concentrations in sediments and in interstitial waters from the FunkaBay. $a$ : Stn. 1, 42-16.2N, 140-36.0E, water depth is $90 \mathrm{~m}$.

ㅁ: Total $\mathrm{Hg}$; ०: $\mathrm{CH}_{3} \mathrm{Hg}-\mathrm{Hg}$ in interstitial water; $\bullet: \mathrm{CH}_{3} \mathrm{Hg}-\mathrm{Hg}$ in sediment

b : Stn. 2, 42-24.0N, 140-31.0E, water depth is $96 \mathrm{~m}$.

ㅁ : Total $\mathrm{Hg}$; O: $\mathrm{CH}_{3} \mathrm{Hg}-\mathrm{Hg}$ in interstitial water; $\bullet: \mathrm{CH}_{3} \mathrm{Hg}-\mathrm{Hg}$ in sediment 
showed that methylmercury reacts with hydrogen sulfide to produce a volatile sulfur derivative of methylmercury. It is generally assumed that methylmercury exists in natural waters and that aquatic organisms concentrate it, because it has been detected in all aquatic organisms. Attempts to detect methylmercury in natural waters have been made by CHAU and SAITOH (1973) and ANDREN and HARRISS (1975).

If the high mercury concentration in the upper sediment is due to accumulation of mercury by benthic organisms, similar distributions may be seen for the other heavy metals. As shown in Fig. 5, however, the concentrations of copper, zinc, iron and lead in the sediments from Stn. 938 show no variation with depth. Similar results were obtained in the other samples from both the Okhotsk Sea and Funka Bay.

Another possibility must be examined: Significant amounts of mercury may be introduced to the surface sediments by industrialization accelerated since 1,900 A.D. According to LISITSYN (1975), the sedimentation rate is 3$10 \mathrm{~cm} 1,000^{-1} \mathrm{y}^{-1}$ in the Okhotsk Sea. If man's activities since 1,900 caused the increase in mercury concentration in the surface sediments, then the anthropogenically derived mercury should be observed only in the top $1 \mathrm{~cm}$ of the cores. In addition, the mercury concentration in present sea water with normal salinity is nearly constant at $5 \mathrm{ng} l^{-1}$ regardless of depth

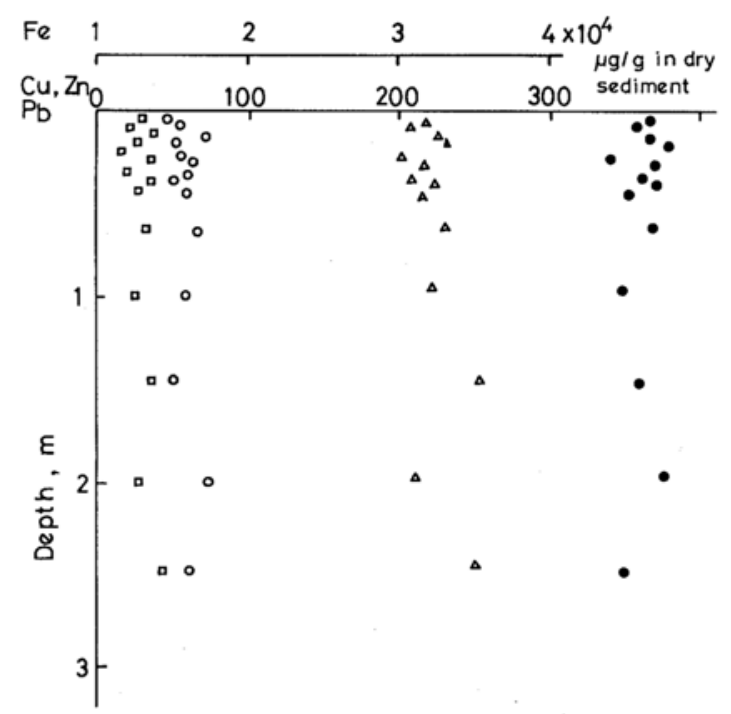

Fig. 5. Copper, zinc, iron and lead concentrations in sediments at Stn. 938.

०: $\mathrm{Cu} ; \bullet: \mathrm{zn} ; \triangle: \mathrm{Fe} ;$ ㅁ: $\mathrm{Pb}$
(Matsunaga, et al., 1975) and also there was no variation of mercury concentration in the oceans at least during the last several decades (MATSUNAGA, 1976).

Based on the above arguments, we favour an early natural diagenetic process as a cause of mercury enrichment in the surface sediments. Mercury is transported to the sediment by associating organic matter (MATSUNAGA, et al., 1976). During bacterial decomposition of organic matters, mercury may be released into interstitial waters and eventually lost from the sediment by forming soluble mono- or di-methylmercury or by volatilizing as its sulfur derivatives.

\section{REFERENCES}

ANDren, A. W. and Harriss, R. C. (1973) Methylmercury in estuarine sediments. Nature 245, 256257.

ANDREN, A. W. and HARRISS, R. C. (1975) Observation on the association between mercury and organic matter dissolved in natural waters. Geochim. Cosmochim. Acta 39, 1253-1257.

Aston, S. R., Bruty, D., Chester, R. and PAdGham, R. C. (1973) Mercury in lake sediments: a possible indicator of technological growth. Nature 241, 450451.

Batti, R., Magnaval, R. and Lanzola, E. (1975) Methylmercury in river sediments. Chemosphere 1, 13-14.

ChaU, Y. K. and SAITOH, H. (1973) Determination of methylmercury in lake water. Int. J. Am. Water Assoc. 58, 723-741.

CowgILL, U. M. (1975) Mercury contamination in a 54-m core from Lake Huleh. Nature 256, 476-478.

JENSEN, S. and JERNELOV, A. (1969) Biological methylation of mercury in aquatic organisms. Nature 223, 753-754.

JERNELOV, A. (1970) Release of methylmercury from sediments with layers containing inorganic mercury at different depths. Limnol. Oceanogr. 15, 958-960.

LANGLEY, D. G. (1973) Mercury methylation in an aquatic environment. J. WPCF. 45, 44-51.

LISITSYN, A. P. (1975) The rate of recent sedimentation in the oceans. Oceanology 11, 790-802.

MatsunaGa, K., Nishimura, M. and Konishi, S. (1975) Mercury in the Kuroshio, Oyashio regions and the Japan Sea. Nature 258, 224-225.

MATSUNAGA, K. (1976) Estimation of variation of mercury concentration in the oceans during the last several decades. J. Oceanogr. Soc. Japan 32, 48-50.

Matsunaga, K. and TAKAHASHI, S. (1976) Coldvapor atomic absorption spectrometric determination 
of nanogram amounts of organic mercury in sediments or aquatic organisms. Anal. Chim. Acta 87, 487-489.

MatsunaGa, K., Shiraki, Y. and Kobayashi, R. (1976) Mechanism of mercury elimination from sea water. Paper presented at the annual meeting of the Oceanographical Society of Japan, Tokyo, Apr. 1976.

Nishimura, M., Matsunaga, K. and Konishi, S. (1975) Determination of mercury in natural waters. Japan Analyst 24, 655-658.

Rowland, I. R., DaVIES, M. J. and Grasso, R.
(1977) Volatilisation of methylmercuric chloride by hydrogen sulfide. Nature 265, 718-719.

SiKeS, C. S. and Drain, M. P. (1973) Mercury in lakes. Nature 244, 529.

Spangler, W. J., Spigarelli, J. L., Rose, J. M. and MILLER, H. M. (1973) Methylmercury: bacterial degradation in lake sediments. Science 180, 192-193.

YounG, D. R., Johnson, J. N., Souter, A. and ISAACS, J. D. (1973) Mercury concentrations in dated varved marine sediments collected off southern California. Nature 244, 273-274. 